\title{
Matematika eta Euskal dantzak
}

\author{
(Mathematics and Basque Dances)
}

Osane Oruetxebarria*, Judith Rivas

Matematika Saila, Zientzia eta Teknologia Fakultatea, Leioako Campusa (UPV/EHU)

LABURPENA: Pentsa daiteke matematika eta dantza bata bestetik oso urrun dauden diziplinak direla eta haien arteko loturak topatzea ezinezkoa dela. Artikulu honetan hori horrela ez dela erakutsiko dugu. Betaurreko matematikoak jantzita, geometriako oinarrizko kontzeptuak erraz aurkituko ditugu. Alde batetik, dantzariek, taldean antolatzean, zirkunferentziak, laukizuzenak eta beste poligono batzuk sortzen dituztela ikusiko dugu; bestetik, haien posizioen artean dauden simetriak deskribatuko ditugu biraketen, translazioen eta islapenen laguntzaz. Kontzeptu sakonagoak edo hain bistakoak ez direnak ere erabiliko ditugu zenbait dantza deskribatzeko, hala nola, konbinatoriako permutazioak eta konbinazioak, baita topologiaren barruan dagoen txirikorden teoria ere.

HITZ GAKOAK: Euskal dantzak, matematika, simetriak, permutazioak, konbinazioak, txirikorden teoria.

ABSTRACT: Mathematics and dance may be thought as disciplines very far away one from each other and it may seem that finding links between them is impossible, but in this paper we will show that this is not true. Wearing mathematical glasses, we will easily find basic geometrical concepts. On one hand, we will see that dancers, when organized in groups, form circumferences, rectangles and other polygons; on the other hand, we will describe symmetries among dancers' positions, by means of rotations, translations and reflections. We will also describe other dances making use of deeper and less obvious concepts, such as permutations and combinations from combinatorics and braid theory from topology.

KEYWORDS: Basque dances, mathematics, symmetries, permutations, combinations, braid theory.

\footnotetext{
* Harremanetan jartzeko / Corresponding author: Osane Oruetxebarria. Matematika Saila, Zientzia eta Teknologia Fakultatea (UPV/EHU), Sarriena Auzoa, z/g (48940 Leioa, Euskal Herria). - osane.oruetxebarria@ehu.eus - https://orcid.org/00000002-9757-446X.

Nola aipatu / How to cite: Oruetxebarria, Osane; Rivas, Judith (2021). "Matematika eta Euskal dantzak»; Ekaia, 39, 2021, 229-255. (https://doi.org/10.1387/ekaia.21529).

Jasoa: 2020, martxoak 11; Onartua: 2020, abuztuak 8.

ISSN 0214-9001 - elSSN 2444-3255 / (c) 2021 UPV/EHU
}

(i) (i) Obra hau Creative Commons Atribución 4.0 Internacional-en lizentziapean dago 


\section{SARRERA}

Hasiera batean artea eta matematika zerikusirik ez duten diziplinak direla pentsa daitekeen arren, antzinatik ezaguna da matematikaren erabilera adierazpen artistiko desberdinetan. Ziur aski, adibide nabarienak simetriena eta proportzioarena dira, arkitekturan, eskulturan edo pinturan ez ezik dantzan ere edertasunarekin lotu ohi direnak. Koreografoek dantzarien kokapena eskenatokian eta egingo dituzten urratsak pentsatzen dituztenean, ohikoa da simetrian oinarritutako arauei jarraitzea, dantza-lana ikuslearentzat erakargarria izan dadin.

Beste alde batetik, azken urteetan dantzaren eta matematikaren arteko erlazioa aurkako noranzkoan erabili dutenak ere badaude, hau da, dantza erabili dutenak zenbait kontzeptu matematiko modu entretenigarriagoan ulertarazteko.

Artikulu honetan euskal dantzak aztertuko ditugu eta matematikaren arlo desberdinekin dituzten lotura batzuk azalduko ditugu. Adibidez, testu osoan zehar ikusiko dugunez, zortzi zenbakia hainbat esparrutan agertuko da: musikaren egituran eta dantzarien kopuruan, besteak beste.

Ezaguna da musikaren eta matematikaren arteko erlazioa eta hori izango da gure abiapuntua, dantza ez delako musikarik gabe ulertzen. Dantzaren urratsak musikara egokitzen dira eta musika konpasen bidez neurtzen da modu matematikoan.

Gainera, izen matematikoak erabiltzen dira dantzan: balletean besoen eta hanken posizioak izendatzeko zenbakiak erabiltzen dira, saltsaren pauso askoren izenak zenbakiak dira eta tangoaren irudi bat zortziak izenekoa da. Euskal dantzetan ere zenbakiekin eta matematikako beste kontzeptu batzuekin erlazionatutako izenak ditugu eta horiek artikuluaren 3. atalean aipatuko ditugu.

Euskal dantza gehienak taldeka dantzatzen dira eta talde horietako dantzariak modu ordenatu batean antolatzen dira irudi geometrikoak sortuz. 4. atalean bi multzotan sailkatuko ditugu dantzak, dantzariek poligonoak edo irudi zirkularrak osatzen duten, horren arabera.

Geometriarekin jarraituz, 5. atalean simetriaren kontzeptu matematikoa erabiliko dugu dantzarien posizioak erlazionatzeko. Bi eredu aztertuko ditugu: egitura zirkularrean dantzatzen den arin-arina eta laukizuzen batean egiten den Dantzari-dantzaren Ezpata joko txikia.

Dantzari-dantzaren beste bi parte, Zortzikoa eta Launakoa, izango dira 6. atalean konbinatoriaren ikuspuntutik deskribatuko ditugun dantzak. Konbinatoria ordenamenduez eta taldekatzeez arduratzen den matematikaren adarra da, eta hori da, hain zuzen ere, Zortzikoaren eta Launakoaren ezaugarri matematiko nabariena, Dantzari-dantzaren beste zati batzuetan errepi- 
katzen dena. Adibidez, Binakoan dantzariek binaka dantzatzen dute; beraz, Launakoarekin egingo dugun analisi bera errepika daiteke.

Euskal dantzetan egingo dugun ibilbide matematikoari bukaera emateko, 7. atalean Topologiaren kontzeptu konplexuago bat azalduko dugu: txirikorden teoria. Iruleak eta zinta-dantza izeneko dantzetan, dantzarien urratsen bidez, txirikordak sortzen direla ikusiko dugu. Lehen kasuan imajinatu behar dugu txirikorda eta bigarrenean fisikoki ikus daiteke zutoinaren gainean. Bi dantza horien arteko ezberdintasunak irudi geometrikoekin dauka zerikusia: bi lerro paralelotan antolatzen dira dantzariak Irulean, eta zirkunferentzia bat eratuz zinta-dantzan.

Dantzak hitzen bidez ondo deskribatzea zaila gerta daitekeenez, bibliografian zenbait bideoren estekak sartu dira, irakurleak ematen diren azalpenak hobeto uler ditzan.

\section{EUSKAL DANTZAK ETA MUSIKA}

Nabaria da dantzaren eta musikaren arteko erlazioa, bai eta musikaren eta matematikaren artekoa ere. Beraz, musika zubi aproposa izan daiteke dantza eta matematika lotzeko.

Dantzaren urratsak musikaren erritmora egokitzen dira eta musikaren erritmoa konpasen bidez antolatzen da. Konpasa soinuen iraupena matematikoki neurtzeko modua da, pultsu azentuatuak eta ez-azentuatuak txandakatuz, konpasaren hasiera pultsu azentuatuak markatzen duelarik. Beste era batera esanda, konpasa ondoz ondoko bi pultsu azentuaturen arteko pultsu kopurua da [1].

Konpasa adierazteko zatiki bat erabili ohi da. Zenbakitzaileak konpasak dituen pultsu kopurua adierazten du eta izendatzaileak, aldiz, pultsu bakoitzak irauten duen nota-irudia, honako baliokidetasun honen arabera:

$$
\begin{array}{ll}
1=\text { biribila } & 16=\text { kortxeaerdia } \\
2=\text { zuria } & 32=\text { fusa } \\
4=\text { beltza } & 64=\text { fusaerdia } \\
8=\text { kortxea } &
\end{array}
$$

Ikus daitekenez, nota-irudi guztiak 2ren berreturak erabiliz idazten dira. Horrela, 2/4ko konpasak bi pultsu ditu, lehenengoa azentuatua eta bigarrena ez-azentuatua, eta pultsu bakoitzak beltz baten iraupena du. Arinarina 2/4ko konpasean idatzitako musikarekin dantzatzen da. Esaldi musikalak 8 konpaseko multzoetan antolatzen dira eta arin-arinaren urratsek 16 konpas irauten dute. 
4/4ko konpasak lau pultsu ditu eta pultsu bakoitzak beltz bat dirau. Kontrapasa 4/4ko konpasean idatzitako musika da, eta Agurra da, ziur aski, kontrapas baten erritmora dantzatzen den euskal dantzarik ezagunena. Hala ere, badago kontrapas izeneko dantza ere. Jauziak izeneko dantzetarako musikan ere 4/4ko konpasa agertzen da.

3/4ko konpasa beltz baten iraupena duten hiru pultsuz osatuta dago. Fandangoak 3/4ko konpasean idatzitako musikari jarraitzen dio. Esaldi musikalak 8 konpaseko taldeetan antolatuta daude eta fandangoaren urrats bakoitzak 16 konpaseko iraupena du.

Bestalde, 6/8ko konpasak sei pultsu ditu, pultsuaren iraupena kortxearena izanik. Konpas hau biribilketaren musikan agertzen da, esaldi musikalek 16 konpas dituztelarik.

Arestian aipatutako konpasak beste herrialdeetako dantzatzeko musikan ere agertzen dira. Horrela, pasodoblea edo merengea 2/4ko konpasean dantzatzen dira; 4/4ko konpasa dagokie, besteak beste, tangoari, foxtrotari edo saltsari; eta 3/4ko konpasa baltsari.

Aitzitik, Euskal musikan dantzarekin lotura estua izan duten konpas berezi bi aipatu behar ditugu: zortzikoa eta ezpata-dantza. Lehenengoa 5/8ko konpasean idazten da, eta bigarrena lehenago aipatu ditugun 6/8ko eta 3/4ko konpas konbinatuetan.

Bi konpas mota hauek bitxiak dira: beste musika herrikoietan ez da antzekorik ezagutzen, doinu berdinarekin behintzat. Horregatik, askotan euskal arrazaren ikur gisa hartu izan dira, baina dantzarako konpas original bi baino ez dira, danbolinaren musikan jatorria dutenak.

Oinarrian, bost-zortziko konpasa hiru pultsutan markatzen da, lehenengoaren neurria bat izanik eta beste biena bikoitza, hau da, zortzi kortxeetatik bost agertuko dira 1-2-2 egitura jarraituz (1. irudia). Horretaz gain, bigarren eta hirugarren pultsuetako lehen notak puntudunak izango dira gehienetan, hiru pultsuak honako modu honetan deskonposatuz pultsu bakoitzaren barneko zatiketa simetrikoa ez izatea eraginez.

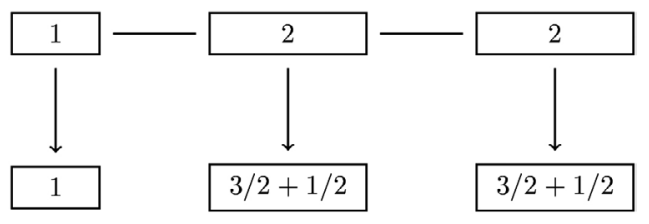

1. irudia. 5/8ko konpasaren egitura.

Atzera begiratuz, 5/8ko konpasari buruzko lehenbiziko erreferentziak XVIII. mendekoak omen dira [2]. Jakina denez mende hori Ilustrazioaren 
garaia zen, eta dena ikuspuntu arrazional batetik aztertzen zen, non arau matematikoak bete behar ziren, simetria besteak beste. Beraz, erritmoak simetrikoa izan behar zuen eta zortzikoarenak ez zuen hori betetzen. Oro har, konpas guztietan lehen pultsua indartsuena izaten da eta besteak ahulagoak, baina 5/8aren kasuan lehen pultsuaren neurria beste bien erdia izanik, pultsu hori ahula bihurtzen da eta jarraian pultsu sendo bat dugu, bigarrena hain zuzen ere. Musikan gertaera honi sinkopa deritze eta errepikatzen denean erritmoa sinkopatua dela esaten da. Hori da zortzikoaren kasuan gertatzen dena, konpas horri berezitasuna ematen diona.

\section{IZEN MATEMATIKOAK EUSKAL DANTZETAN}

Euskal dantzetan matematikarekin lotura duten izenak bilatzen ditugunean zenbakiak agertzen dira gehienbat. Ziur aski guztioi burura etortzen zaigun lehen izen matematikoa aurreko atalean agertu den zortzikoa da. Esan bezala, zortzikoa 5/8ko konpasean idatzitako musika da eta ezaugarri nagusia da zortzi konpaseko esaldiak dituela; hortik datorkio izena.

Hala ere, zortziko hitzak beste esanahi batzuk ditu dantzaren arloan. Lantzeko zortzikoa edo Baztango zortzikoa Nafarroan egiten diren dantzak dira eta haien musika ez dago 5/8ko konpasean idatzita, 2/4ko konpas bitarrean baizik.

Zortzikoa Dantzari-dantzaren parte bat da ere, eta ez da matematikarekin erlazioa duen bakarra. Dantzari-dantza Durangaldeko dantza sorta bat da, bederatzi zati dituena: Agintariena, Zortzinangoa (edo Zortzikoa), Ezpata joko txikia, Banangoa (edo Banakoa), Binangoa (edo Binakoa), Ezpata joko nagusia, Launangoa (edo Launakoa), Makil dantza eta Txontxongiloa.

Dantzari-dantzan zortzi dantzarik parte hartzen dute. Zortzinangoan zortzi dantzariek aldi berean dantzatzen dute; Banangoan dantzariek banaka egiten dituzte beren urratsak, bata bestearen ondoren; Binangoan, aldiz, binaka aritzen dira dantzariak; azkenik, Launangoan, lau dira aldi berean dantzan ari diren dantzariak. Beraz, izenak une bakoitzean dantzatzen diren dantzarien kopuruari egiten dio erreferentzia.

Jauzien zenbait urratsen izenetan ere zenbakiak erabiltzen dira. Jauziak Euskal Herriko eskualde kontinentaleko dantza ezagunenetariko bat da [3]. Haren urratsen artean lau urrats, ezker-hiru eta eskuin-hiru ditugu. Bestalde, urrats batzuei «eta hiru» gehitzen zaie oinarrizko pausoaren bariazio bat adierazteko, hala nola, erdizka eta hiru, zote eta hiru edo ebats eta hiru. Pika bietan edo erdizka lauetan izenetan, zenbakiak adierazten du zenbat aldiz errepikatu behar den oinarrizko urratsa [4].

Baztango bi mutil-dantzaren izenetan ere zenbakiak agertzen dira, Zazpi jauziak eta Hiru puntukoa dantzetan, hain zuzen ere. Bigarrenean, 
gainera, zenbakia ez den beste kontzeptu matematiko bat agertzen da, puntua. Geometriarekin zerikusia duen termino matematiko hori dantza horren urrats baten izena ere bada. Azkenik, bat eta erdi Baztango mutil-dantza gehienetan egiten den urrats baten izena da.

\section{EUSKAL DANTZAK ETA IRUDI GEOMETRIKOAK}

Euskal dantzak eta Matematikak duten beste lotura nabaria irudi geometrikoena da. Atal honetan horien adibide batzuk aztertuko ditugu, bi talde handitan sailkatuz. Alde batetik, biribilean edo korroan egiten diren dantzak, eta bestetik poligono forma desberdinak eginez dantzatzen direnak. Azken hauekin hasiko gara.

Bai gizonezkoen zein emakumezkoen euskal dantza askotarako zortzi dantzari behar dira. Zenbaki horrek ematen duen oinarrizko egiturari jarraituz lortzen den poligonoa laukizuzena da, oinarrian bi dantzari eta altueran lau dantzari egonik $(2 \times 4)$ edo alderantziz, $(4 \times 2), 2$. irudian ikus daitekeenez.

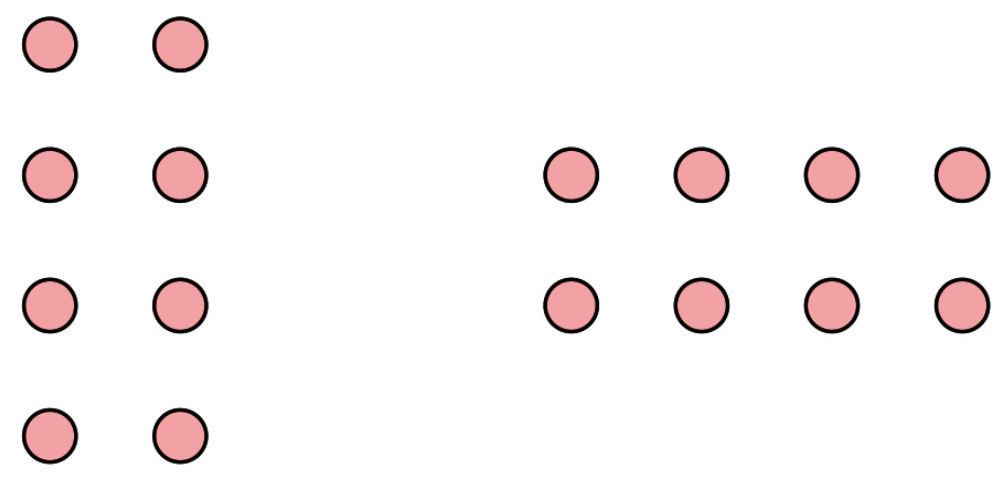

2. irudia. Dantzariak modu ordenatuan kokatzen dira, laukizuzenak sortuz zenbait dantzatan (ezkerrean $2 \times 4$, eskuinean $4 \times 2$ ).

Irudi geometriko hau ohikoa da eta herrialde askotako dantzetan aurki daiteke, besteak beste, Bizkaiko Makil dantzan eta Gorulariaren arku dantzan; Arabako Pipaongo dantzetan eta Villabuenako Makil dantzetan; Nafarroako Otsagabiako dantzetan; Nafarroa Behereko Sorginak eta Euskaldunak dantzetan.

Gipuzkoako Brokel dantzaren sortako Uztai txiki eta Makil dantzan $2 \times 4$ laukizuzenaren egitura bera errepikatzen da, baina, taldeaz gain, askotan buruzagiaren irudia agertzen da, dantzaren lehen parteak berak eginez eta pentagono (3. irudia) bat sortuz $[5,6]$. 


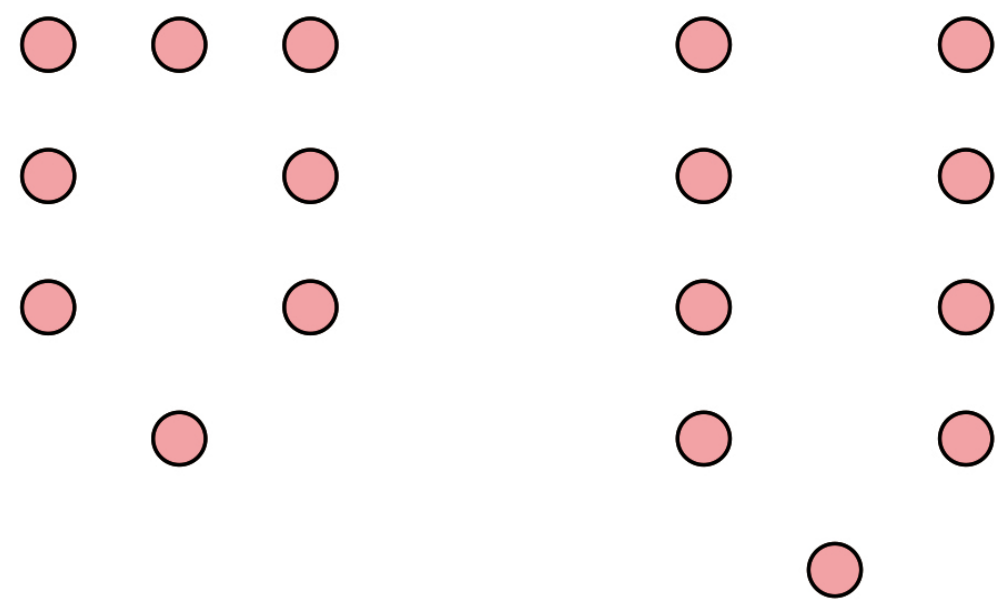

3. irudia. Banakoa (ezkerrean) eta Brokel dantza (eskuinean): dantzariak pentagono baten aldeetan kokatzen dira.

Laukizuzenaren itxura duten dantzetan, batzuetan egitura hori mantendu egingo da dantzan zehar, eta beste batzuetan dantza garatuz doan heinean beste poligono desberdin batzuk ager daitezke. Bizkaiko Dantzari-dantzan kasu bi horien adibideak ditugu. Alde batetik, Launako izeneko dantzan, laukizuzen forma mantentzen da dantza guztian zehar [7]. Bestetik, Banakoan, Binakoan eta Txotxongiloan beste irudi geometriko batzuk azaltzen dira. Banakoaren kasuan, izenak dioen bezala, dantzariak bakarka egiten du dantza eta atzean gainerako zazpi dantzariak daude, irudian ikus daitekeen pentagonoa lortuz (3. irudia). Brokel dantzan 9 dantzarik parte hartzen dute eta Banakoan, aldiz, $8 \mathrm{k}$.

Binakoari dagokionez, bikoteka dantzan egiterakoan, beste laukizuzen bat (4. irudia) sortuko da. Oraingo honetan, oinarri batean 4 pertsona egongo dira, zutabe bakoitzean 3 , eta azken oinarria zabalik geldituko da, alde bat falta zaion poligonoaren itxura hartuz [7].

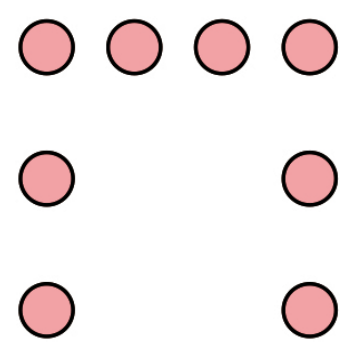

4. irudia. Binakoan agertzen den laukizuzen irekia. 
Azkenik, Txotxongiloaren kasuan hexagono bat (5. irudia) irudikatuko dute dantzariek. Hasieran lehenengo lerroko ezker aldean dagoen dantzaria erdira pasatuko da bakarka dantza egiteko, altxatua izan baino lehenago. Dantzaren atal horretan hiru zutabe agertuko dira, aldeetako lerroetan bi pertsona egonik eta erdikoan lau, horietako lehenengoa eta azkena aurrerago eta atzerago, hurrenez hurren, poligonoaren bi erpinak irudikatuz [7].

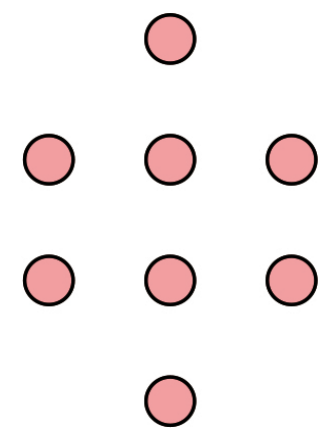

5. irudia. Txotxongiloan agertzen den hexagonoa.

Biribilean egiten diren dantzei dagokienez, agertzen den irudi geometrikoa zirkunferentzia da, 6 . irudian erakusten den bezala. Hainbat dantzaren kasuan ez dago aldez aurretik partaideen kopuru finkorik, beraz, zirkunferentzia tamaina askotakoa izan daiteke. Horren adibide gisa honako dantza hauek aipa ditzakegu: Paganoseko Txulalai, fandangoa eta arinarina, Lapurdiko edo Xiberoako jauziak, Iribaseko ingurutxua.

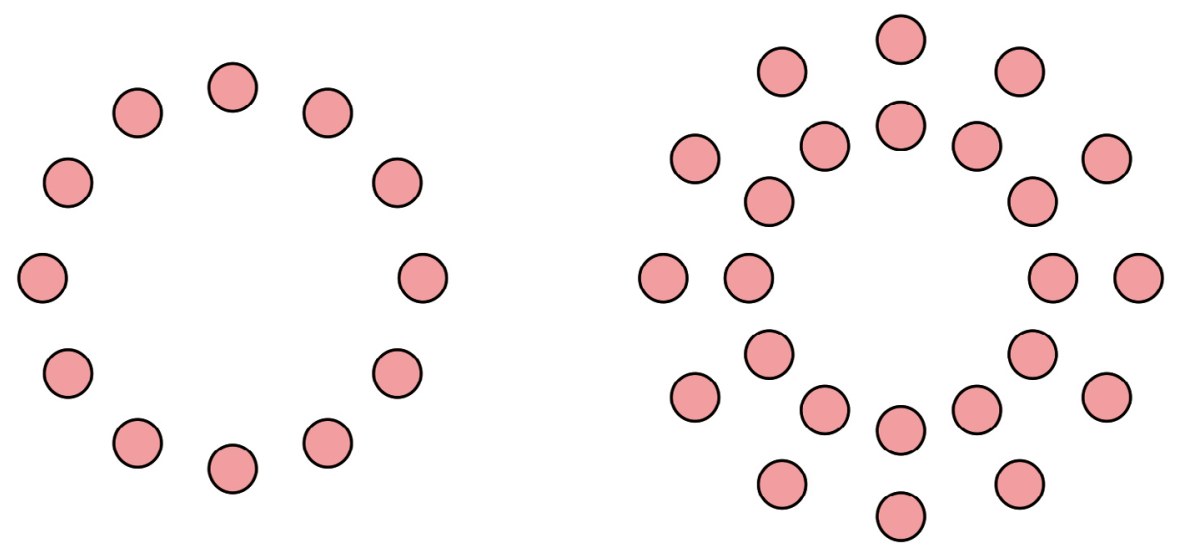

6. irudia. Zirkunferentzia Txulalain, jauzietan edo ingurutxuan (ezkerrean) eta zirkunferentzia zentrokideak arin-arinean eta fandangoan (eskuinean). 
Batzuetan, zirkunferentzia zentrokide bi azaltzea gerta daiteke (6. irudia). Fandangoan eta arin-arinean, adibidez, bikoteka dantzatuz gero, partaide guztiak zirkunferentzia berean egon daitezke, bikotea bata bestearen ondoan egonik; edo aurrez aurre jarrita, zirkunferentzia bat bestearen barruan geratuz $[8,9]$. Gauza bera gertatzen da Iribaseko ingurutxuaren kasuan.

Badaude biribilean egiten diren beste dantza batzuk zeinetan korroa ez den guztiz ixten, eta horren ondorioz zirkunferentziaren zatia agertuko da (erdia kasu askotan, 7. irudia). Horren adibideak honako hauek dira: Zapatain dantza, Lekeitioko andrazkoen aurreskua, Bizkaiko erregelak eta sokadantzak.

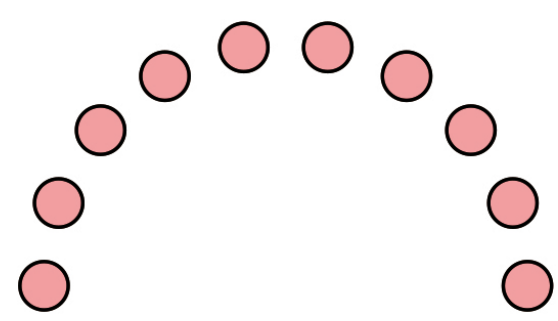

7. irudia. Zirkunferentzia erdia soka-dantzan edo erregeletan.

Partaideen kopurua finkoa izanik, zirkunferentzia osatzen duen dantza Xemeingo Ezpata dantza da. Hamahiru dantzari daude eta horietako batek ardatzarena egingo du, erdian jarriz eta gainerako hamabiak gurutzatuz joango dira zirkunferentzia osatu arte. Gainera, haien ezpatekin zirkunferentziaren erradioak eta ebakitzaileak argi ikus daitezke, 8. irudiko marrazkia sortaraziz. Gernikako Arbola dantzan ere egitura hori errepikatuko da.
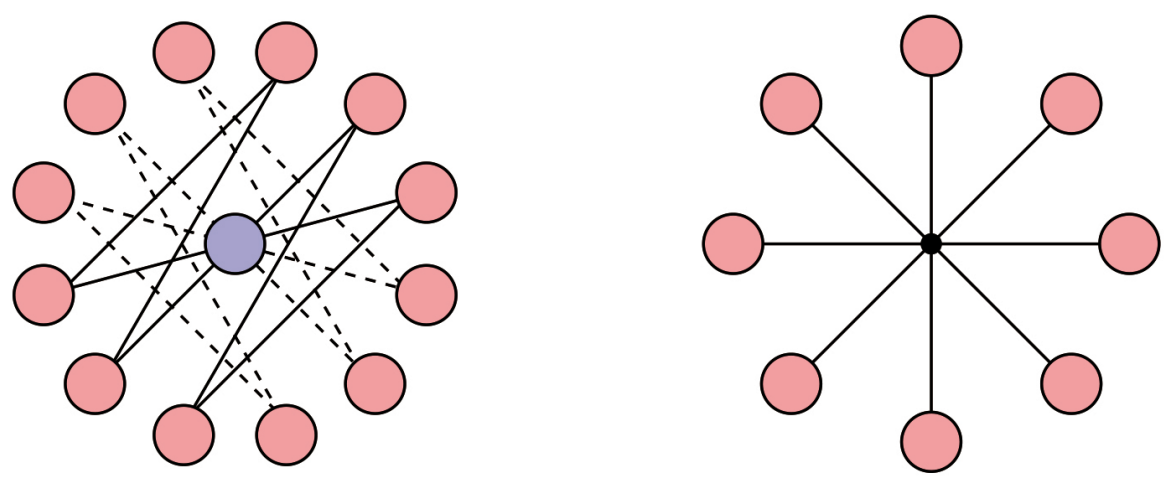

8. irudia. Zirkunferentzia, erradioak eta ebakitzaileak Xemeingo Ezpata Dantzan [7] (ezkerrean). Zirkunferentzia eta erradioak Zinta-dantzan (eskuinean). 
Azkenik, biribilean egiten den dantza ezagunenetariko bat aipatu behar dugu, zinta-dantza hain zuzen ere. Hainbat zinta-dantza mota daude, Bizkaian, Gipuzkoan, Araban edo Nafarroan, koreografia desberdinekin baina ezaugarri komun batzuekin. Oro har 8 dantzarik egingo dute dantza, baina 6, 10 edo 12-rekin ere egin daiteke. Gainera, ardatz bati lotuta egongo dira. Horrek ondorengo atal batean aztertuko ditugun Matematikako beste kontzeptu batzuk agertzea eragingo du.

\section{EUSKAL DANTZAK ETA SIMETRIAK}

Artean ez ezik, dantzan ere simetria edertasunarekin erlazionatzen da. Koreografoek askotan simetria erabiltzen dute mugimendu erakargarriak sortzeko. Has gaitezen simetria era matematikoan definituz. Hori egiteko behar diren egitura matematikoen definizioak [10] erreferentzian aurki daitezke.

Definizioa. Izan bitez $A_{1}$ eta $A_{2}$ bi espazio euklidear afin. $f: A_{1} \rightarrow A_{2}$ aplikazio afina isometria dela diogu baldin eta

$$
d(f(a), f(b))=d(a, b), \quad \forall a, b \in A_{1},
$$

non $d$ distantzia euklidearra den.

Hau da, isometriek distantziak mantentzen dituzte eta, ondorioz, angeluak ere bai. Guk aztertuko ditugun isometriak zuzen, plano edo espazio errealean egongo dira definituta, hau da, $A_{1}=A_{2}=\mathbb{R}^{n}$ izango da, $n=1,2,3$ izanik.

Definizioa. Izan bitez $A$ espazio euklidear afina eta $f: A \rightarrow A$ isometria. $a, b \in A$ puntuak $f$-rekiko simetrikoak direla diogu baldin eta $f(a)=b$ bada. Era berean, $B, D \subset A$ multzoak $f$-rekiko simetrikoak direla diogu baldin eta $f(B)=D$ bada.

Isometriek talde bat osatzen dute konposizioarekiko, hau da, bi isometrien konposizioa isometria da; eta isometria baten alderantzizkoa isometria da [10].

$\mathbb{R}^{n}$ espazioko oinarrizko isometriak translazioak, biraketak eta simetria ortogonalak edo islapenak dira. Ikus dezagun nola definitzen diren.

Definizioa. Izan bitez $\mathbb{R}^{n}$ espazio euklidearra erreferentzia sistema kanonikoarekin eta $\vec{u} \in \mathbb{R}^{n}$. Orduan, $t_{\vec{u}}: \mathbb{R}^{n} \rightarrow \mathbb{R}^{n}$ non $t_{\vec{u}}(x)=x+\vec{u}$ den $x \in \mathbb{R}^{n}$ guztietarako, translazioa dela diogu.

Definizioa. Izan bedi $\alpha \in[0,2 \pi)$. Jatorrian zentrua duen $\alpha$ angeluko biraketa era honetan definitzen da: $b_{\alpha}: \mathbb{R}^{2} \rightarrow \mathbb{R}^{2}$ non 


$$
b_{\alpha}(x, y)=\left(\begin{array}{cc}
\cos \alpha & -\sin \alpha \\
\sin \alpha & \cos \alpha
\end{array}\right) \cdot\left(\begin{array}{c}
x \\
y
\end{array}\right)
$$

den $(x, y) \in \mathbb{R}^{2}$ guztietarako. Era berean, OZ ardatzarekiko $\alpha$ angeluko biraketa $b_{\alpha}: \mathbb{R}^{3} \rightarrow \mathbb{R}^{3}$ aplikazioa da, non

$$
b_{\alpha}(x, y, z)=\left(\begin{array}{ccc}
\cos \alpha & -\sin \alpha & 0 \\
\sin \alpha & \cos \alpha & 0 \\
0 & 0 & 1
\end{array}\right) \cdot\left(\begin{array}{l}
x \\
y \\
z
\end{array}\right)
$$

$\operatorname{den}(x, y, z) \in \mathbb{R}^{3}$ guztietarako.

Ohartu $\mathbb{R}^{3}$ espazioko ardatz bertikalarekiko biraketak ez duela aldatzen azken koordenatua, eta lehen bi koordenatuak planoko biraketak ematen dituenak direla. Hots, espazioko $O Z$ ardatzarekiko biraketa $O X Y$ planoarekiko paraleloa den plano bateko biraketa da.

Definizioa. $f: \mathbb{R}^{n} \rightarrow \mathbb{R}^{n}$ aplikazio afina simetria ortogonala edo islapena dela diogu baldin eta $f \circ f(x)=x$ bada $x \in \mathbb{R}^{n}$ guztietarako.

Izan bitez $f: \mathbb{R}^{n} \rightarrow \mathbb{R}^{n}$ simetria ortogonala, $x \in \mathbb{R}^{n}$, eta $m=\frac{x+f(x)}{2}$ puntua $x$ eta $f(x)$ puntuak lotzen dituen zuzenkiaren erdiko puntua. Orduan, $f(m)=m$ da, hots, $m f$-ren puntu finkoa da.

Puntu finkoa bakarra bada, $m \in \mathbb{R}^{n}, f$ simetria zentrala dela esaten da eta $s_{m}$ idatziko dugu; $L$ zuzen baten puntu guztiak $f$-ren puntu finkoak badira, orduan, $f=s_{L}$ ardatz-simetria dela diogu eta zuzen hori simetria-ardatza da; $n=3$ bada, $\Pi$ plano batean dauden puntu guztiak $f$-ren puntu finkoak badira, $f=s_{\Pi}$-ri ispilu-simetria deritzo eta plano horri, simetria-plano.
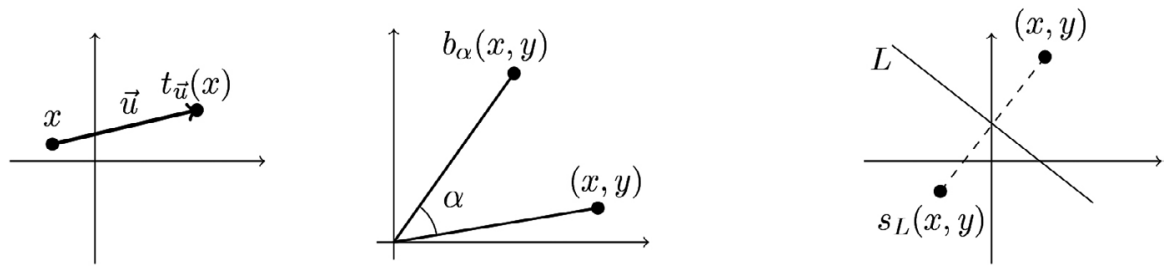

9. irudia. Translazioak, biraketak eta zuzen batekiko islapenak planoan.

Azter ditzagun euskal dantzetan agertzen diren simetria batzuk. Lehenengo eta behin, dantzarien posizioak hartuko ditugu kontuan. Dantzariek espazioko bolumen bat betetzen dute, beraz, hiru dimentsioko espazioan definitutako isometriak bila daitezke. Dena den, agertuko diren translazioe- 
tan eta biraketetan, norabide bertikalean ez da aldaketarik egongo, hots, planoko transformazioak balira bezala har daitezke. Era berean, islapenetan simetria-planoak bertikalak izango dira eta, ondorioz, $O X Y$ planoko proiekzioak zuzenak izango dira, eta zuzen horiekiko simetria ortogonalak izango ditugu $O X Y$ planoan. Horregatik, irudietan dantzarien $O X Y$ planoko proiekzioak erabiliko ditugu, proiekzio horiek zirkuluak direla onartuz, eta aipatuko ditugun isometriak planoan definituta egongo dira.
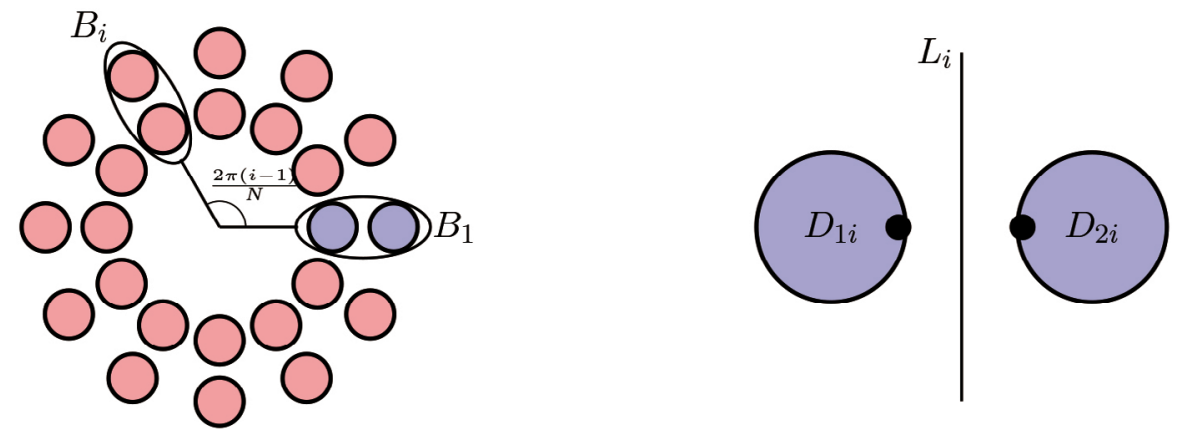

10. irudia. Biraketak (ezkerrean) eta islapenak (eskuinean) arin-arinean edo fandangoan.

Aurreko atalean azaldu den bezala, arin-arina eta fandangoa dantzatzeko, dantzariak bi zirkunferentzia zentrokidetan kokatzen dira [8,9].

Demagun $N$ dantzari daudela zirkunferentzia bakoitzean. 10. irudian azaltzen den bezala, izan bedi $B_{i}$ barruko zirkunferentzian dagoen dantzari batek eta haren aurrean dagoen kanpoko zirkunferentziako dantzariak osatzen duten bikotearen posizioa, $i=1, \ldots, N$ guztietarako. Orduan, $B_{i}$ bikotearen posizioa $B_{1}$ bikotearena biratuz lortzen da,

$$
B_{i}=b_{\frac{2 \pi}{N}(i-1)}\left(B_{1}\right), \quad i=1, \ldots, N .
$$

Bestalde, izan bitez $D_{1 i} B_{i}$ bikotearen barruko zirkunferentzian dagoen partaidearen posizioa, eta $D_{2 i}$ kanpoko zirkunferentzian dagoenarena. Barruko dantzariak ezkerreko hankarekin egiten dituen urratsak, kanpoko zirkunferentziarenak eskuinekoarekin egiten ditu eta berdin beste edozein urrats egitean. Ondorioz, $L_{i}$ baldin bada haien erdian gelditzen den zuzena, zuzen horrekiko islapena dugu:

$$
D_{2 i}=s_{L_{i}}\left(D_{1 i}\right), \quad i=1, \ldots, N .
$$

Aztertuko dugun bigarren dantza Dantzari-dantzaren Ezpata joko txikia da [7]. Dantza horretan zortzi dantzarik hartzen dute parte, laukizuzen ba- 
tean kokatuta. Gainera, dantzariek ezpata bat daramate eskuineko eskuan. Horregatik, irudietan dantzari bat adierazten duen zirkuluak zuzenki bat dauka itsatsita.

Dantzaren hasieran, dantzari guztiak aurrera begira daude, 11. irudian ikusten den bezala. Ondorioz, $D_{i}$ dantzariaren posizioa $D_{1}$ dantzariaren posizioari $O X Y$ planoan definitutako translazio bat aplikatuz lortzen da. $O X$ ardatzean unitatea $D_{1}$ eta $D_{2}$ zirkuluen zentroen arteko distantzia da; aldiz, $O Y$ ardatzean, unitatea $D_{1}$ eta $D_{3}$ zirkuluen zentroen arteko distantzia da. 11. irudiaren eskuinaldean ematen dira posizioen arteko simetriak aipatutako translazioen bidez.

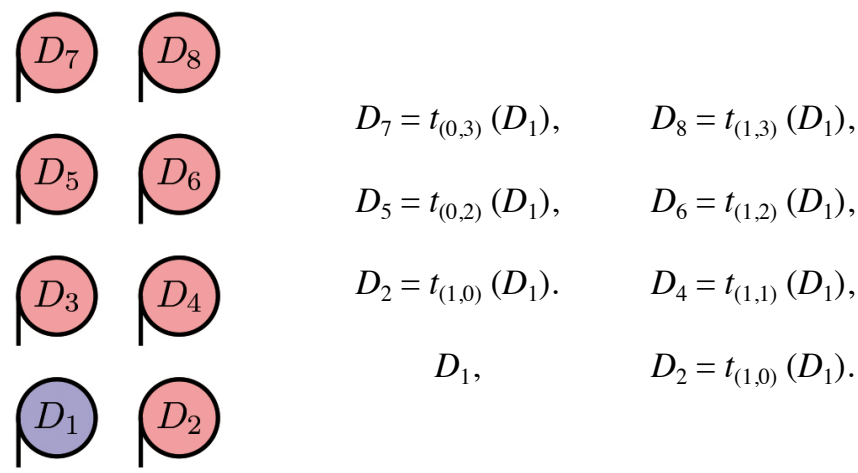

11. irudia. Ezpata joko txikiaren lehen posizioa. Dantzari guztien posizioak ezkerreko beheko muturrean dagoen dantzariaren translazioak dira.

Seigarren konpasaren bukaeran, dantzarien kokapena 12. irudikoa da. Dantzari batzuk aurrera begira daude eta besteak, atzera, binaka aurrez aurre daudelarik. Orain, $B_{i j} D_{i}$ eta $D_{j}$ dantzariek osatzen duten bikotearen posizioa bada, $B_{24}, B_{57}$ eta $B_{68}$ posizioak $B_{13}$-ri translazio egokiak aplikatuz lortzen dira, honela:

$$
\begin{array}{cc}
B_{57}=t_{(0,2)}\left(B_{13}\right), & B_{68}=t_{(1,2)}\left(B_{13}\right), \\
B_{13}, & B_{24}=t_{(1,0)}\left(B_{13}\right) .
\end{array}
$$

Bestalde, $B_{13}$ bikotearen barruan beste simetria mota bat dugu. Kasu honetan, esan den bezala, dantzariek ezpata daramate eskuineko eskuan. Gainera, dantzari guztiek urratsak oin berarekin egiten dituzte. Horregatik, $D_{3}$ dantzariaren posizioa $D_{1}$ dantzariaren posizioa $O X Y$ planoan $\pi$ anplitudeko angelu bat biratuz lortzen da, biraketa zentroa haien zentroak lotzen dituen zuzenkiaren erdiko puntua izanik. Oro har,

$$
D_{i+2}=b_{\pi}\left(D_{i}\right), \quad i=1, \ldots, 6 .
$$



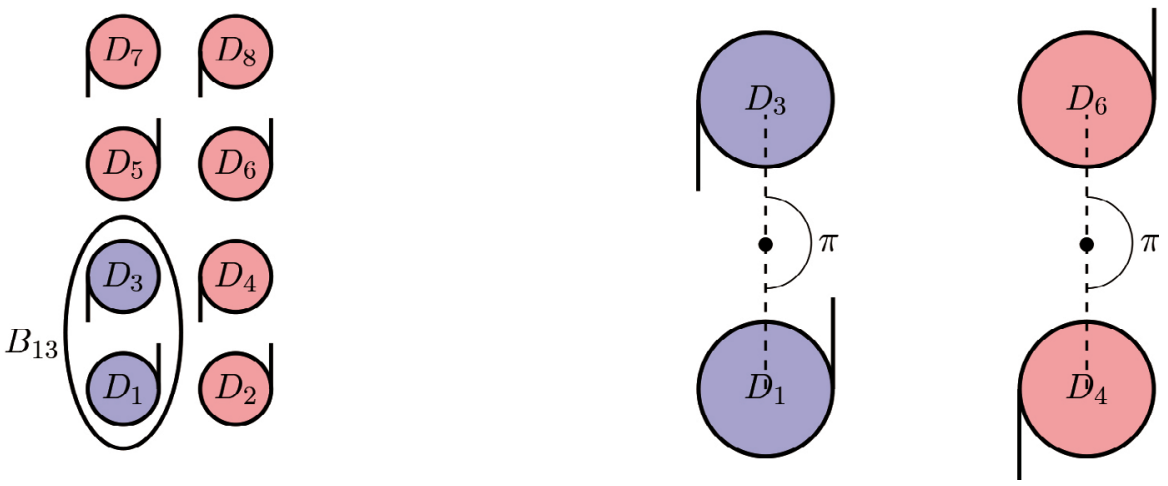

12. irudia. Ezpata joko txikiaren bigarren posizioa. Translazioak eta biraketak.

Zortzigarren konpasaren bukaeran, dantzariak 13. irudiaren ezkerraldean agertzen den hirugarren konfiguraziora heltzen dira. Ezkerreko zutabeko dantzariak eskuinetara begira eta eskuineko zutabekoak ezkerretara, bi lerroak aurrez aurre gelditzen direlarik. Lehen erabili dugun notazioarekin, lehen eta bigarren dantzariek osatzen duten bikotearen posizioari translazio bertikalak aplikatuz, beste bikoteen posizioak lortzen ditugu, honela:

$$
\begin{aligned}
& B_{78}=t_{(0,3)}\left(B_{12}\right), \\
& B_{56}=t_{(0,2)}\left(B_{12}\right), \\
& B_{34}=t_{(0,1)}\left(B_{12}\right) .
\end{aligned}
$$
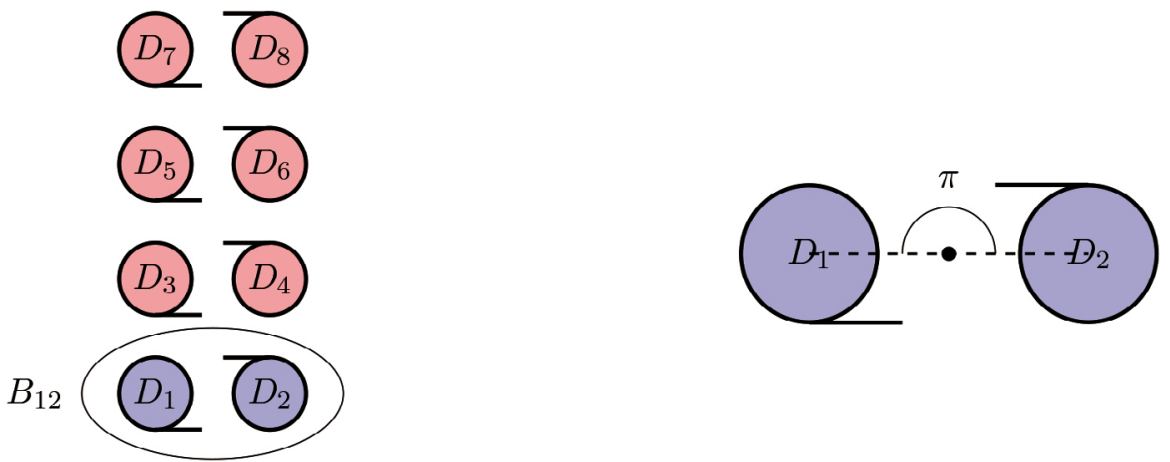

13. irudia. Ezpata joko txikia. Dantzarien hirugarren posizioa eta agertzen diren simetriak.

Gainera, bigarren posizioan gertatu den bezala, bikote bakoitzaren bi partaideak simetrikoak dira $\pi$ anplitudeko biraketa batekiko,

$$
D_{i+1}=b_{\pi}\left(D_{i}\right), \quad i=1,3,5,7 \text {. }
$$


Aztertuko dugun azken konfigurazioa 14. irudian ikus daiteke eta 10. konpasaren bukaeran agertzen da.

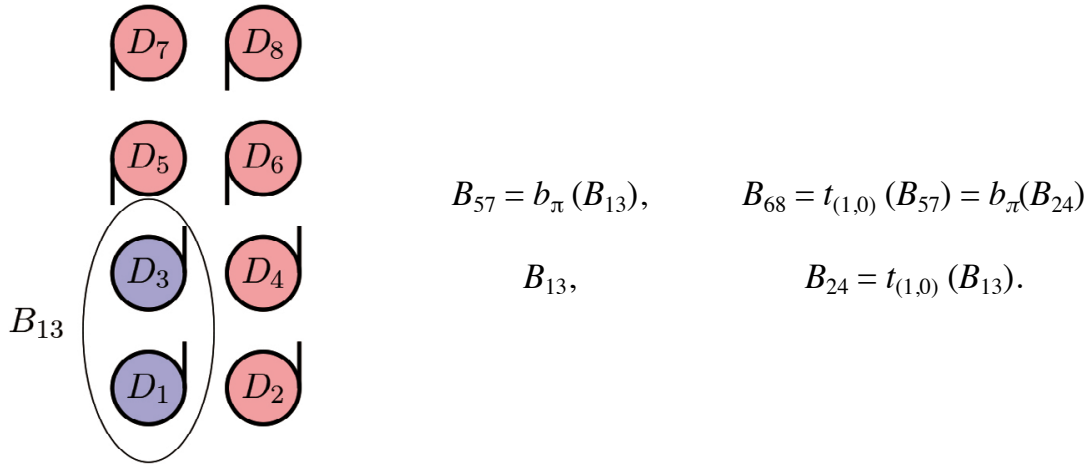

14. irudia. Ezpata joko txikia. Dantzarien laugarren posizioa.

Kasu honetan lehen lau dantzariak atzera begira daude eta azkeneko laurak, aldiz, aurrera. Lehen eta hirugarren dantzariek osatzen duten bikoteari translazio horizontal bat aplikatuz, bigarren eta laugarren dantzarien bikotea lortzen da. Aldiz, $B_{57}$ lortzen da $B_{13}$ biratuz. Era berean, $B_{13}$ erabiliz, $B_{68}$ lortu nahi bada, translazio baten eta biraketa baten konposizioa egin behar da:

$$
B_{68}=\mathrm{t}_{(1,0)} \circ b_{\pi}\left(B_{13}\right)=b_{\pi} \circ t_{(1,0)}\left(B_{13}\right) .
$$

Atal honi bukaera emateko, denboran agertzen diren simetriak ere aipatuko ditugu. Dantza mugimendua da eta, ondorioz, denboraren dimentsioa ere har daiteke kontuan. Dantzariek egiten dituzten urratsak dantzan zehar errepikatzen dira.

Arin-arinean dantza 16 konpaseko blokeetan antolatzen da. Lehen 4 konpasetan egiten diren urratsak errepikatzen dira 4 aldiz (batzuetan azken 4 konpasetan trantsizio-urrats bat egiten da eta oinarrizko pausoa 3 aldiz soilik errepikatzen da). 16 konpaseko bloke bakoitzean urratsez aldatzen da baina egitura bera mantentzen da. Beraz, denbora-unitatea 4 konpaseko blokea bada, eta $U_{i}$ erabiltzen bada 4 konpaseko $i$-garren blokean egiten diren urratsak adierazteko, orduan,

$$
U_{i}=t_{i}\left(U_{1}\right), \quad i=2,3,(4)
$$

lortzen dugu. Ezpata joko txikian, dantzariek urrats bera errepikatzen dute konpas guztietan, beraz, hemen ere, denboran translazio bat egiten da, denbora-unitatea konpasa izanik. Gainera, lau konpaseko bloke batean (arin- 
arinean), edo konpas bakarrean (Ezpata joko txikian), eskuineko oinarekin hasten bada mugimendua, hurrengoan ezkerrekoarekin hasten da. Hau da, denborarekiko translazioaz gain, dantzariaren gorputzaren ezkerreko eta eskuineko atalak banatzen dituen plano bertikalarekiko islapena dago espazioan.

\section{DANTZARI-DANTZA ETA KONBINATORIA}

Lehenago ikusi dugunez, Euskal dantzen konfigurazioak aztertuz gero, hainbat egitura errepikatu egiten dira. Matematikan, emandako elementu kopuru baten taldekatze edo ordenatze prozesuak aztertzen dituen arloa Konbinatoria da. Atal honetan Dantzari-dantzako Zortzikoan, Ezpata joko nagusian eta Launakoan agertzen diren Konbinatoriako kontzeptu bi aztertuko ditugu: permutazioak (ordenatze-problemak) eta konbinazioak (aukeraketa-problemak) [11].

Ikus ditzagun, lehenik eta behin, egitura matematikoa finkatzeko behar ditugun oinarrizko kontzeptu batzuk.

Definizioa. Izan bedi $n$ elementu dituen multzoa, $A=\{1,2,3, \ldots, n\}$. $A$-tik $A$-ra doan aplikazio bijektiboari permutazio deritzogu. Horrela, $n$ elementu dituen multzoaren permutazioen multzoa $\Sigma_{n}$-ren bidez izendatuko dugu, hau da,

$$
\Sigma_{n}=\{\sigma:\{1,2,3, \ldots, n\} \rightarrow\{1,2,3, \ldots, n\}, \sigma \text { bijekzioa }\} .
$$

Bere kardinala $n !=n \cdot(n-1) \cdots \cdot 2 \cdot 1$ da eta zenbaki honek ematen du zenbat modu desberdinetan ordena daitezkeen $\{1,2,3, \ldots, n\}$ multzoko elementuak.

Permutazio bat adierazteko erabiltzen den notazio erraz bat honako hau izan daiteke

$$
\left(\begin{array}{cccc}
1 & 2 & \ldots & n \\
\sigma(1) & \sigma(2) & \ldots & \sigma(n)
\end{array}\right),
$$

non lehen lerroan 1-etik n-rako elementuak ordenatuta kokatzen diren, eta bigarren lerroan, goiko bakoitzari dagokion irudia. Adibidez

$$
\sigma=\left(\begin{array}{llll}
1 & 2 & 3 & 4 \\
3 & 4 & 1 & 2
\end{array}\right) .
$$

Hori horrela, $\Sigma_{n}$ multzoan $\sigma$ eta $\tau$ permutazioen biderkadura ohiko funtzioen konposizioaren bidez definitzen da, hau da,

$$
\sigma \tau=\tau \circ \sigma .
$$


Modu horretan definitutako eragiketak taldearen egitura ematen dio $\Sigma_{n}$ multzoari, $\left(\Sigma_{n}, \cdot\right) n$ ordenako talde simetrikoa deritzoguna, hain zuzen ere [12].

Dantzari-dantzaren Zortzikoan zortzi dantzari $2 \times 4$-ko laukizuzen batean kokatzen dira eta dantzan zehar haien tokiak elkarrekin trukatzen dituzte 15. irudiaren arabera [7]. Beraz, kasu honetan, $n=8$ da eta dagokion $\Sigma_{8}$ talde simetrikoan 40.320 permutazio desberdin daude. Azter ditzagun horietatik zeintzuk diren Zortzikoan agertzen direnak eta betetzen dituzten propietateak.
(7) 8
(6) (5)
(5) 6
(1) (2)
(5) (6)
(8) 7
(7) 8
(3) (4)
(3) (4)

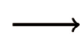
$\stackrel{\sigma_{2}}{\longrightarrow}$
(1) (2)
(5) 6
(1) (2)
(4) (3)
(3) (4)
(7) 8
1. posizioa
2. posizioa
3. posizioa
4. posizioa

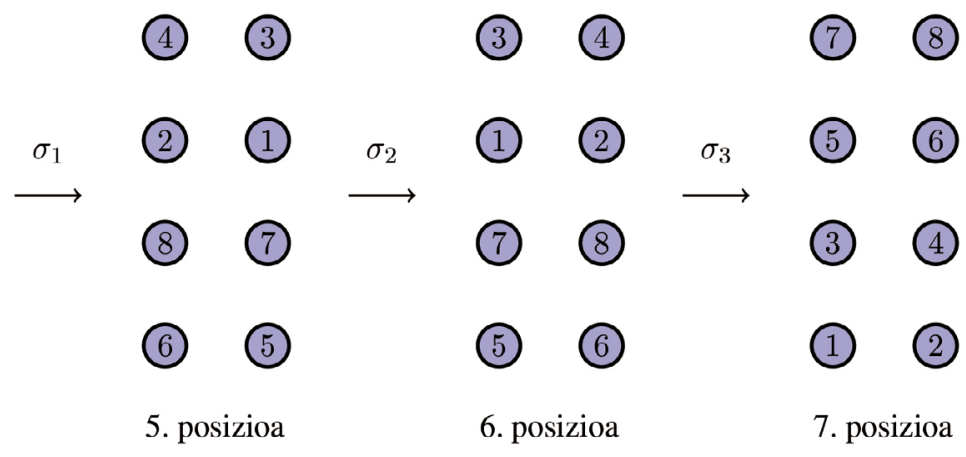

15. irudia. Zortzikoa. Dantzariak tokiz aldatzen dira dantzan zehar, hasierako posiziora bueltatuz dantzaren bukaeran.

Lehenengo eta behin, aurreko laukian dauden lau dantzariek diagonal berean dauden dantzariekin trukatzen dituzte tokiak, 15. irudiko bigarren posiziora pasatuz, eta gauza bera egiten dute atzeko laukian daudenek. Hau da,

$$
\sigma_{1}=\left(\begin{array}{llllllll}
1 & 2 & 3 & 4 & 5 & 6 & 7 & 8 \\
4 & 3 & 2 & 1 & 8 & 7 & 6 & 5
\end{array}\right)
$$


permutazioa aplikatuz pasatzen da lehen posiziotik bigarrenera. Gero, dantzariek zutabez aldatzen dira, 15 . irudiko 3 . posizioa,

$$
\sigma_{2}=\left(\begin{array}{cccccccc}
1 & 2 & 3 & 4 & 5 & 6 & 7 & 8 \\
2 & 1 & 4 & 3 & 6 & 5 & 8 & 7
\end{array}\right)
$$

permutazioa jarraituz. Hirugarren mugimenduan aurreko laukiko dantzariak atzeko laukira doaz, 15. irudiko laugarren posiziora heltzeko. Permutazioen notazioarekin,

$$
\sigma_{3}=\left(\begin{array}{llllllll}
1 & 2 & 3 & 4 & 5 & 6 & 7 & 8 \\
5 & 6 & 7 & 8 & 1 & 2 & 3 & 4
\end{array}\right)
$$

Hiru permutazio hauek aplikatu ondoren, hasierako taldea alderantziz kokatuta dugu, hau da, lehen lerroa orain laugarrena da, bigarren lerroa hirugarren lerroa izatera pasatu da, hirugarren lerroa oraingo bigarrena da eta laugarren lerroa orain lehenengoa da (15. irudiaren laugarren laukizuzena). Posizio horretatik abiatuta, berriz $\sigma_{1}, \sigma_{2}$ eta $\sigma_{3}$ permutazioak aplikatuz gero ordena horretan, hasierako taldea lortzen dugu, hau da, dantzari bakoitza hasierako tokira bueltatu da [13], 15. irudian ikus daitekeen bezala.

Hizkuntza matematikoan adieraziz, izan bedi id identitate aplikazioa, hau da aldaketarik eragiten ez duen permutazioa. Zortziko dantzan hiru permutazio erabiltzen dira, bakoitza bi bider, honako modu honetan: $\sigma_{1} \sigma_{2} \sigma_{3} \sigma_{1} \sigma_{2} \sigma_{3}$, hasierako posizioa berreskuratzeko. Beraz,

$$
\left(\sigma_{1} \sigma_{2} \sigma_{3}\right)^{2}=i d
$$

dela esan dezakegu.

Ideia hau oinarritzat hartuz, Dantzari-dantzaren Ezpata joko nagusia ere azter dezakegu [7]. Dantza horretan, Zortzikoan bezala, zortzi dantzarik hartzen dute parte eta haien posizioak elkarrekin trukatzen dituzte, $\sigma_{2} \sigma_{4} \sigma_{2} \sigma_{3}$ birritan eginez, non $\sigma_{2}$ eta $\sigma_{3}$ Zortzikoko permutazio berdinak diren eta

$$
\sigma_{4}=\left(\begin{array}{cccccccc}
1 & 2 & 3 & 4 & 5 & 6 & 7 & 8 \\
3 & 4 & 1 & 2 & 7 & 8 & 5 & 6
\end{array}\right)
$$

den. Dantzaren bukaeran dantzari guztiek beren hasierako posizioak berreskuratzen dituzte; beraz, honako erlazio hau dugu:

$$
\left(\sigma_{2} \sigma_{4} \sigma_{2} \sigma_{3}\right)^{2}=i d .
$$

Permutazioek zenbat modu desberdinetan ordena daitezkeen multzo bateko elementuak ematen badigute, multzo horretan dauden elementuak zenbat modu desberdinetan aukera daitezkeen, konbinazioek ematen digute. Konbinazioak, $n$ elementu ezberdinetatik osaturiko $k$-kote posibleen kopu- 
rua kalkulatzeko erabiltzen dira, ordena kontuan hartu gabe. Adibidez, $a, b, c$ eta $d$ lau letretatik zenbat bikote osa daitezke lau elementu horien ordena kontuan hartu gabe. Matematikoki $K_{n}^{k}$ moduan adierazten dira eta kopurua $\left(\begin{array}{l}n \\ k\end{array}\right)(n$ gain $k$ ) zenbaki konbinatorioaren bidez kalkulatzen da, hau da,

$$
K_{n}^{k}=\left(\begin{array}{l}
n \\
k
\end{array}\right)=\frac{n !}{k !(n-k) !}=\frac{n \cdot(n-1) \cdots \cdot 2 \cdot 1}{(k \cdot(k-1) \cdots \cdot 2 \cdot 1)((n-k) \cdot(n-k-1) \cdots \cdot 2 \cdot 1)} .
$$

Dantzari-dantzako Launakoaren kasuan, dantza bi zatitan bana daiteke [7]. Lehen partean dantzariek launaka egiten dute dantzan, 16. irudian agertzen den ordenean.
(7) (8)
(7)
(7)
(8)
(7) 8
(5) (6)
(5) (6)
(5) (6)
(5) (6)
(3) (4)
(3) (4)
(3) (4)
(3) (4)
(1) (2)
(1) (2)
(1) (2)
(1) (2)
(7) 8

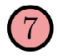
(8)
(7)
(8)
(7) 8
(5) (6)
(5) (6)
(5) 6
(5) 6
(3) (4)
(3) (4)
(3) (4)
(3) (4)
(1) (2)
(1) (2)
(1) (2)
(1) (2)

16. irudia. Launakoaren lehen zatia. More koloreko dantzariek dantzatzen duten bitartean, besteak geldirik daude.

Lehen zatia aztertuz gero, multzoaren kopurua $n=8$ da eta launaka dantzan egiteko $K_{8}^{4}=70$ aukera desberdin daude. 16. irudian azaltzen den bezala, hona hemen agertzen diren konbinazioak:

$$
\begin{aligned}
& k_{1}=\{1,2,3,4\}, \quad k_{2}=\{5,6,7,8\}, \quad k_{3}=\{1,2,5,6\}, k_{4}=\{3,4,7,8\}, \\
& k_{5}=\{1,3,5,7\}, \quad k_{6}=\{2,4,6,8\}, \quad k_{7}=\{1,3,6,8\}, \quad k_{8}=\{2,4,5,7\} .
\end{aligned}
$$


Bigarren zatian zortziko bat egiten dute hasierako posiziora bueltatzeko, aipatutako $\sigma_{3} \sigma_{2} \sigma_{1}$ permutazioaren bidez.

\section{IRULEAK, ZINTA-DANTZA ETA TXIRIKORDEN TEORIA}

Orain arte azaldutakoaren arabera, dantzariek sortzen dituzten irudiak edota irudi horiek eragindako egitura matematikoak aztertu ditugu. Atal honetan, bide horretatik jarraituz eragile berri bat gehituko dugu, dantzarako erabiltzen den tresna, zinta hain zuzen ere, eta dantzariek euren dantzetan zintez baliatuz sortzen duten Matematika arakatuko dugu. Horretarako, Topologiako adarra den Txirikorden teoria erabiliko dugu. Emil Artin matematikariak garatu zuen teoria hau 1947. urtean [14], eta han, txirikordak egiteko prozesuan zehar sortzen diren egitura matematikoak azaltzen zituen.

Oro har, zintekin egiten diren dantzak bi ataletan sailka daitezke: zintak ardatz finko bati loturik biribilean egiten diren dantzak, eta zinten mutur bakoitza zuzenki bati lotuta egonik eta zuzenkiak paraleloak izanik, dantzatzen direnak. Lehen multzoan Zinta-dantza (zuhaitz-dantza, kordoidantza) izen orokorrarekin ezagutzen diren dantzak ditugu. Hori horrela, Bizkaiko zinta-dantza eta Domingiluen dantza ditugu, Brokel-dantzen sortakoa den Gipuzkoako zinta-dantza [15], Arabako Pipaon herriko zintaedo zuhaitz-dantza, edo Nafarroako Corteseko zinta-dantza, besteak beste [16] Bestalde, zintak paraleloki hartuz Iruleak izeneko dantza dugu. Sailkapen honen arabera, egitura matematiko desberdinak azalduko zaizkigu Txirikorden teoriaren ikuspuntutik; beraz, ikus ditzagun, hasteko, teoria horren oinarrizko kontzeptu batzuk.

Txirikorda bat barra batetik zintzilikatzen diren zenbait kordaren multzoa da. Korda horiek beren artean gurutzatzen dira, beti beherantz doaz eta haien beheko muturrak beste barra bati lotuta daude [17]. Egitura geometriko honi talde egitura bat [12] esleitu ahal zaio eragiketa bat definituz txirikorden artean, biderketa, hain zuzen ere. Bi txirikorden arteko biderketa bigarrena lehenengoaren azpian jarriz. Eragiketa honekiko identitatea gurutzaketarik gabeko txirikorda da. Gainera, taldea oinarrizko txirikorda batzuek sortua da, elementu sortzaileak izenaz ezagutzen direnak, eta honela definitzen direnak:

$\sigma_{i}: \quad i$-garren korda $i+1$-garren kordaren gainetik pasatzen da,

$\sigma_{i}^{-1}: \quad i+1$-garren korda $i$-garren kordaren gainetik pasatzen da $\equiv$ $i$-garren korda $i+1$-garren kordaren azpitik pasatzen da. 


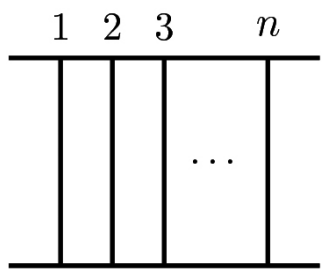

id

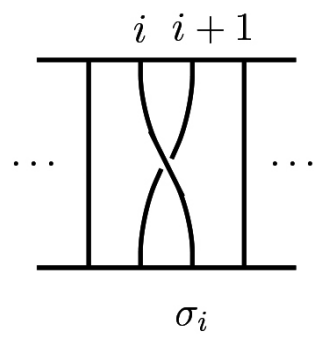

17. irudia. Txirikorda identitatea eta elementu sortzaileak.

Elementu sortzaile hauek biderkatuz, txirikorda konplikatuagoak deskriba daitezke. Adibidez, 18. irudiko txirikorda $\sigma_{2} \sigma_{1}^{-1} \sigma_{3}^{-1} \sigma_{2} \sigma_{4} \sigma_{1}^{-1}$ moduan idatz daiteke.

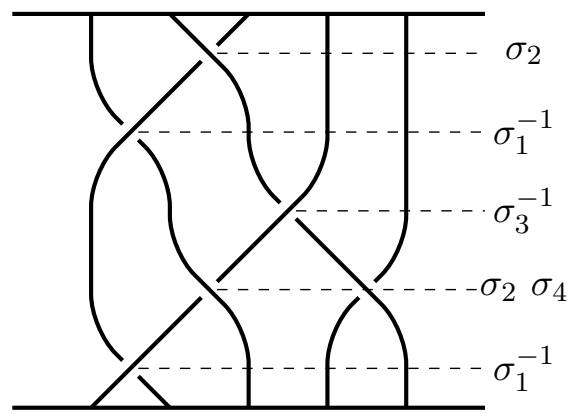

18. irudia. Bost kordako txirikorda.

Artinek frogatu zuen elementu sortzaileek definitutako txirikorden multzoak, erlazio batzuk betetzen badituzte, talde egitura duela. Alde batetik, argi dago biderketa ez dela trukakorra, irudi desberdina sortzen delako gainetik pasatzen den kordaren arabera; beraz, talde ez-trukakorra da. Hala ere, neurri batean eragiketa trukakorra dela ikus daiteke, kordak bata bestetik urruti daudenean, eta propietate honi urrutiko trukakortasuna deitzen zaio. Hau guztia honako definizio honetan formalizatzen da.

Definizioa. $B_{n}$ txirikorden taldea $\sigma_{1}, \ldots, \sigma_{n-1}$ sortzaileek sortutako taldea da non honako erlazio hauek betetzen diren:

- Urrutiko trukakortasuna: $\sigma_{i} \sigma_{j}=\sigma_{j} \sigma_{i},|i-j| \geq 2$ bada.

- Txirikorden erlazioak: $i=1, \ldots, n-2$ guztietarako

1. $\sigma_{i+1} \sigma_{i} \sigma_{i+1}=\sigma_{i} \sigma_{i+1} \sigma_{i}$.

2. $\sigma_{i+1}^{-1} \sigma_{i} \sigma_{i+1}=\sigma_{i} \sigma_{i+1} \sigma_{i}^{-1}$.

3. $\sigma_{i+1} \sigma_{i} \sigma_{i+1}^{-1}=\sigma_{i}^{-1} \sigma_{i+1} \sigma_{i}$. 
Azter dezagun Iruleak dantzan sortzen den txirikorda nola idatzi elementu sortzaileen notazioa erabiliz. Dantza horretan sortzen den txirikorda ez dela fisikoki agertzen esan behar dugu. Dantzan zortzi bikote daude, eta bikote bakoitzak zinta bat du, ezkerretik eskuinera zuria, gorria, berdea, gorria, zuria, gorria, berdea eta gorria ordenari jarraituz, 19. irudian ikus daitekeen erara antolatuta.

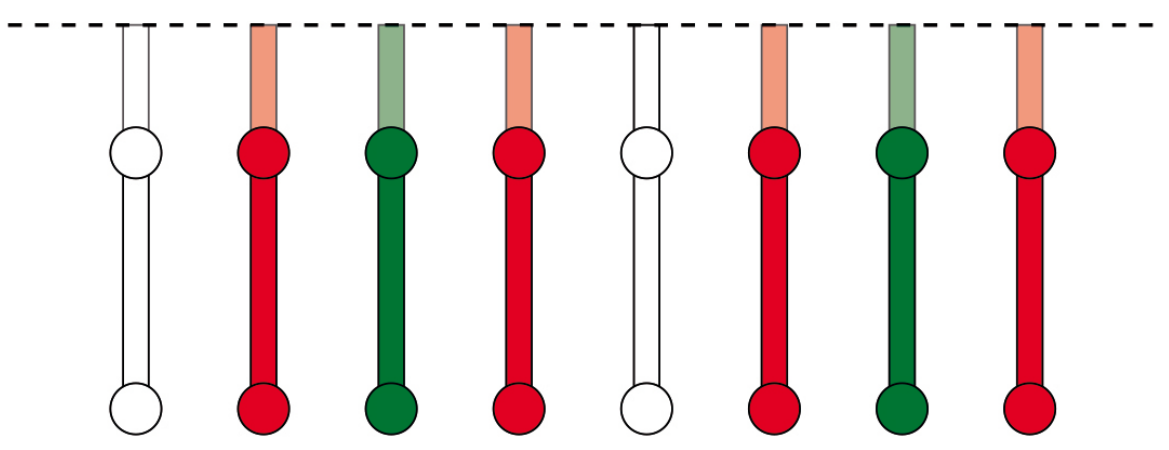

19. irudia. Iruleak. Dantzarien bikoteek zinta bati heltzen diote. Zinta horiek alegiazko txirikorda bat sortzen dute dantzarien mugimenduekin.

Bikoteek zinta bana daramate eta dantzak dirauen bitartean ondoko bikotearen azpitik edo gainetik pasatzen dira. Zintak bikoteen atzean legokeen barra batera lotuta egongo balira, mugimendu horien bidez txirikorda bat sortuko litzateke barra eta dantzarien artean. Kontuan izanik $n=8$ dela, gurutzaketak $\sigma_{1}$-etik $\sigma_{7}$-ra eta $\sigma_{1}^{-1}$-etik $\sigma_{7}^{-1}$-ra joango dira.

Pausoz pauso ikusiz, lehenengo bikotea bigarren bikotearen azpitik pasatzen da eta gero hirugarrenaren gainetik; beraz, txirikorden taldearen notazioa erabiliz, $\sigma_{1}^{-1} \sigma_{2}$ dugu. Gero, lehenengo eta hirugarren posizio berrietan dauden bikoteak haien eskuineko bikoteen azpitik pasatzen dira, ondoren hurrengo bikoteen gainetik pasatzeko, hots, $\sigma_{1}^{-1} \sigma_{3}^{-1} \sigma_{2} \sigma_{4}$ dugu. Hirugarrenez, lehen, hirugarren eta bosgarren posizioetan dauden bikoteak beren eskuineko bikoteen azpitik pasatzen dira eta ondoren hurrengo bikoteen gainetik; beraz, $\sigma_{1}^{-1} \sigma_{3}^{-1} \sigma_{5}^{-1} \sigma_{2} \sigma_{4} \sigma_{6}$ dugu. Azkenik, lehen, hirugarren, bosgarren eta zazpigarren posizioetan dauden bikoteak beren eskuineko bikoteen azpitik pasatzen dira. Orain, zazpigarren posizioan zegoena zortzigarrenean dago eta ez dauka eskuineko bikoterik gainetik pasatzeko, hau da, $\sigma_{1}^{-1} \sigma_{3}^{-1} \sigma_{5}^{-1} \sigma_{7}^{-1} \sigma_{2} \sigma_{4} \sigma_{6}$ eragiketa dugu. Momentu honetan 20. irudiaren (1) blokea amaitu dugu eta dantzaren hasieran ezkerreko muturrean (lehen posizioan) zegoen bikotea eskuineko muturrean dago (zortzigarren posizioan). Ondoren, $\sigma_{1}^{-1} \sigma_{3}^{-1} \sigma_{5}^{-1} \sigma_{7}^{-1} \sigma_{2} \sigma_{4} \sigma_{6}$ blokea lau aldiz errepikatu eta gero 20. irudiaren (2) blokea egin dugu, eta lehen bikotea bere hasierako posiziora itzuliko da. $\sigma_{3}^{-1} \sigma_{5}^{-1} \sigma_{7}^{-1} \sigma_{4} \sigma_{6} \sigma_{5}^{-1} \sigma_{7}^{-1} \sigma_{6} \sigma_{7}^{-1}$ egin ondoren (20. irudiaren (3) blokea), dantzari guztiak hasierako posizioetara itzuli dira [18]. 


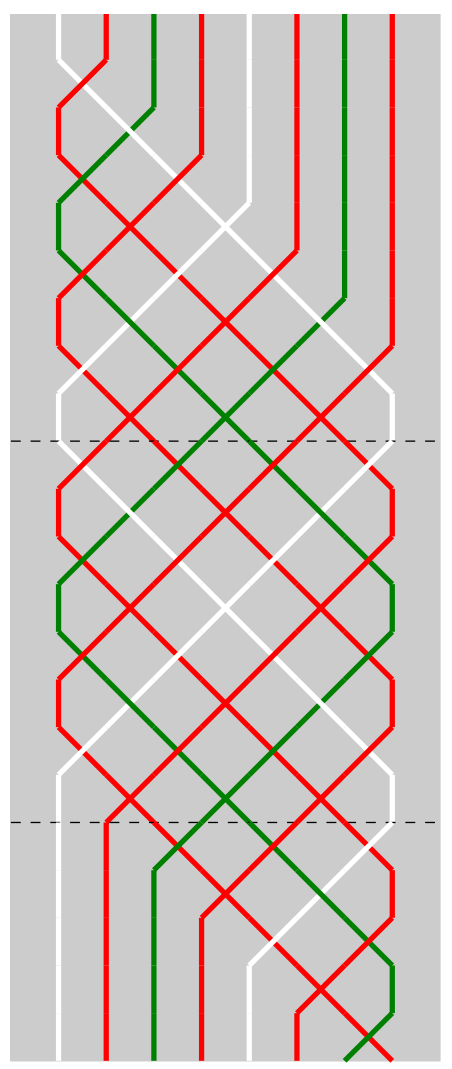

$$
\begin{array}{cccc}
\sigma_{1}^{-1} & & & \\
\sigma_{2} & & & \\
\sigma_{1}^{-1} & \sigma_{3}^{-1} & & \\
\sigma_{2} & \sigma_{4} & & \\
\sigma_{1}^{-1} & \sigma_{3}^{-1} & \sigma_{5}^{-1} & \\
\sigma_{2} & \sigma_{4} & \sigma_{6} & \\
\sigma_{1}^{-1} & \sigma_{3}^{-1} & \sigma_{5}^{-1} & \sigma_{7}^{-1} \\
\sigma_{2} & \sigma_{4} & \sigma_{6} & \\
\sigma_{1}^{-1} & \sigma_{3}^{-1} & \sigma_{5}^{-1} & \sigma_{7}^{-1} \\
\sigma_{2} & \sigma_{4} & \sigma_{6} & \\
\sigma_{1}^{-1} & \sigma_{3}^{-1} & \sigma_{5}^{-1} & \sigma_{7}^{-1} \\
\sigma_{2} & \sigma_{4} & \sigma_{6} & \\
\sigma_{1}^{-1} & \sigma_{3}^{-1} & \sigma_{5}^{-1} & \sigma_{7}^{-1} \\
\sigma_{2} & \sigma_{4} & \sigma_{6} & \\
\sigma_{1}^{-1} & \sigma_{3}^{-1} & \sigma_{5}^{-1} & \sigma_{7}^{-1} \\
\sigma_{2} & \sigma_{4} & \sigma_{6} & \\
& \sigma_{3}^{-1} & \sigma_{5}^{-1} & \sigma_{7}^{-1} \\
& \sigma_{4} & \sigma_{6} & \\
& & \sigma_{5}^{-1} & \sigma_{7}^{-1} \\
& & \sigma_{6} & \\
& & & \sigma_{7}^{-1}
\end{array}
$$

20. irudia. Iruleak. Ezkerraldean dantzaren bukaeran eratu den alegiazko txirikorda eta eskuinaldean gurutzaketen idazkera matematikoa.

Zinta-dantzaren kasuan, dantzariak zirkunferentzia batean kokatuta daude, eskuan zinta bat daramate eta zintak zirkunferentziaren zentroan dagoen zutoin bertikal batera lotuta daude. Dantzarien mugimenduek txirikorda bat sortzen dute zutoinaren gainean. Egoera hori txirikorden talde baten bidez modeliza daiteke, baina orain kordak bi zirkunferentzietara lotuta daude (bata, zutoina, eta bestea, dantzariek osatzen dutena); beraz, txirikorden talde anularra kontsideratu behar da. Ikus dezagun nola definitzen den txirikorden talde anularra. Esan bezala, $n \geq 2$ korda bi zirkunferentziatara lotuta daude eta horrek inplikatzen du $n$-garren korda lehenengoaren ondoan dagoela. Beraz, txirikorden taldean agertzen ez diren bi sortzaile berri ditugu: $\sigma_{0}, n$-garren korda lehenengoaren gainetik pasatzen bada; eta $\sigma_{0}^{-1}$, lehenengo korda $n$-garren kordaren gainetik pasatzen bada.

Gainera, korda guztiak hurrengo posiziora pasatzeko biratu daitezke, hau da, $i$-garren tokian dagoen korda $i+1$-garren tokira eramaten da, 
$i=1, \ldots, n-1$ guztietarako eta $n$-garren korda lehen tokira eramaten da. Transformazio hori $\tau$-ren bidez adieraziko dugu. Sortzaile horiek talde bat sortzen dute zenbait erlazio betetzen badira [19].

Definizioa. Izan bitez $n \geq 2$, eta $\sigma_{0}, \ldots, \sigma_{n-1}, \tau$ lehenago definitutako elementuak. Orduan,

$$
\begin{gathered}
\mathcal{P}_{n}=<\tau, \sigma_{0}, \ldots, \sigma_{n-1}: \sigma_{i} \sigma_{j}=\sigma_{j} \sigma_{i},|i-j| \geq 2 ; \\
\sigma_{i} \sigma_{i+1} \sigma_{i}=\sigma_{i+1} \sigma_{i} \sigma_{i+1}, \tau \sigma_{i} \tau^{-1}=\sigma_{i+1}, \quad i=0, \ldots, n-1>
\end{gathered}
$$

txirikorden talde anularra dela esaten da.

Hau guztia kontuan izanik, azter ditzagun zinta-dantzetan aurki daitezken txirikordak. Oro har zortzi dantzarik egiten dute dantza, zuria, gorria, berdea, gorria, zuria, gorria, berdea, gorria ordenean jarrita, erlojuaren orratzen kontrako noranzkoa hartuz, 21. irudian ikus daitekeenez.

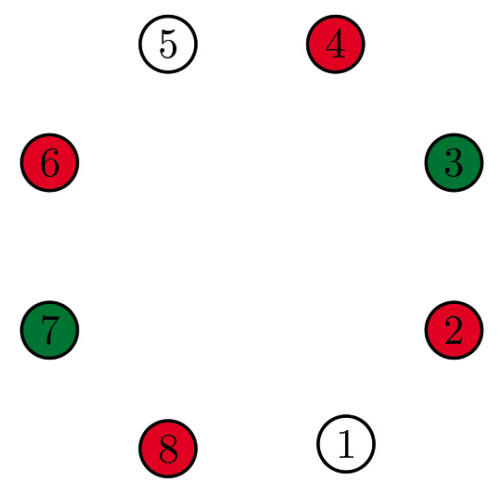

21. irudia. Zinta-dantza. Dantzariak zirkunferentzia batean daude kokatuta, erlojuen orratzen kontrako noranzkoan zenbakituta.

Has gaitezen Bizkaiko zinta-dantza aztertzen [16]. Kasu honetan dantzari guztiak aldi berean hasten dira mugitzen, eta lehen pausoan zinta gorriak bakoitzaren eskuinaldean duten zinta zuriaren edo berdearen gainetik pasatzen dira, hau da, $\sigma_{0} \sigma_{2} \sigma_{4} \sigma_{6}$ eragiketa egin dute. Orain zinta gorriak lehen, hirugarren, bosgarren eta zazpigarren posizioetan daude, hurrenez hurren, eta bakoitzaren eskuinaldean dagoen zintaren azpitik pasatzen dira, hots, $\sigma_{1}^{-1} \sigma_{3}^{-1} \sigma_{5}^{-1} \sigma_{7}^{-1}$ dugu. Egitura hau bi bider errepikatuz dantzari bakoitza aurrez aurreko posiziora iritsiko da, eta beste bi bider eginda, guztiak hasierako posizioetara itzuliko dira. 22. irudian buelta erdiaren grafikoa ikus dezakegu eta dagokion adierazpen matematikoa: 


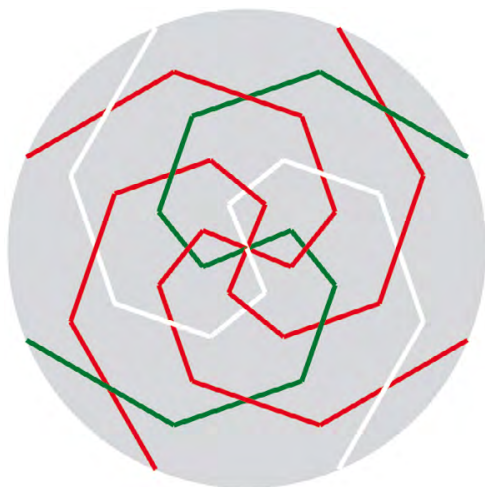

$$
\left.\begin{array}{cccc}
\sigma_{0} & \sigma_{2} & \sigma_{4} & \sigma_{6} \\
\sigma_{1}^{-1} & \sigma_{3}^{-1} & \sigma_{5}^{-1} & \sigma_{7}^{-1} \\
\sigma_{0} & \sigma_{2} & \sigma_{4} & \sigma_{6} \\
\sigma_{1}^{-1} & \sigma_{3}^{-1} & \sigma_{5}^{-1} & \sigma_{7}^{-1}
\end{array}\right\} \text { Buelta erdia }
$$

22. irudia. Bizkaiko zinta-dantza: sortzen den txirikorda eta egiten diren gurutzaketak.

Txirikorda amaituta dago dantzariek lau buelta eman ondoren. Dantza amaitzeko dantzariek alderantzizko eragiketak egingo dituzte txirikorda desegiteko eta hasierako egoera lortzeko.

Gipuzkoako zinta-dantzari dagokionez [15], Bizkaikoarekin alderatuz desberdintasun bat du: dantzariak ez dira guztiak batera dantzan hasten, binaka baizik, musikako pultsu bakoitzarekin, eta behin dantza hasiz gero, jarraitzen dute. Momentu honetatik aurrera, dantzariek Bizkaiko zintadantzan agertu diren gurutzaketak egiten dituzte. Buelta kopuru jakin bat eman ondoren, binaka ere joango dira geldituz. Domingilue dantzan ere horrela gertatzen da, prozedura honek eragiten duen txirikorda honako hau izanik:

$$
\left.\begin{array}{cccc}
\sigma_{0} & & & \\
\sigma_{1}^{-1} & \sigma_{7}^{-1} & & \\
\sigma_{0} & \sigma_{2} & \sigma_{6} & \\
\sigma_{1}^{-1} & \sigma_{3}^{-1} & \sigma_{5}^{-1} & \sigma_{7}^{-1} \\
\sigma_{0} & \sigma_{2} & \sigma_{4} & \sigma_{6} \\
\sigma_{1}^{-1} & \sigma_{3}^{-1} & \sigma_{5}^{-1} & \sigma_{7}^{-1} \\
\sigma_{0} & \sigma_{2} & \sigma_{4} & \sigma_{6} \\
\sigma_{1}^{-1} & \sigma_{3}^{-1} & \sigma_{5}^{-1} & \sigma_{7}^{-1}
\end{array}\right\} 5 \text { aldiz }
$$

Azken adibide moduan, azter dezagun Corteseko zinta-dantza [20]. Dantza honen kasuan elementu berri bat agertzen zaigu, arestian txirikor- 
den talde anularra definitzeko beharrezkoa izan den $\tau$ eragiketa. Dantzariak, guztiak batera biratuz, lekuz aldatzen dira, buelta osoa emanez erlojuaren orientaziori jarraituz, bakoitzaren hasierako tokira itzuli arte, hau da $\left(\tau^{-1}\right)^{8}$ dugu. Dantzaren hurrengo pausoan egindakoa desegiten dute $\tau^{8}$ eragiketaren bidez. Horretaz gain, dantzaren beste pauso jakin batean, bikoteka tokian biratzen dute, bikote bakoitzak haien gaineko buelta oso bat emanez. Hizkuntza matematikoa erabiliz, $\sigma_{0}^{2} \sigma_{2}^{2} \sigma_{4}^{2} \sigma_{6}^{2}$ moduan adierazten da. pauso honen ondoren, lehenago Bizkaiko zinta-dantzan agertu den egitura bera errepikatzen dute. Dantza osoa honako eskema honen bidez adieraz daiteke:

$$
\left.\begin{array}{cccc}
\left(\tau^{-1}\right)^{8} & & \\
\tau^{8} & & & \\
\sigma_{0}^{2} & \sigma_{2}^{2} & \sigma_{4}^{2} & \sigma_{6}^{2} \\
\sigma_{0} & \sigma_{2} & \sigma_{4} & \sigma_{6} \\
\sigma_{1}^{-1} & \sigma_{3}^{-1} & \sigma_{5}^{-1} & \sigma_{7}^{-1} \\
\sigma_{0} & \sigma_{2} & \sigma_{4} & \sigma_{6} \\
\sigma_{1}^{-1} & \sigma_{3}^{-1} & \sigma_{5}^{-1} & \sigma_{7}^{-1}
\end{array}\right\} 6 \text { aldiz }
$$

\section{BIBLIOGRAFIA}

[1] De Pedro, D. 1990. Teoría completa de la música. Real Musical.

[2] Ansorena, J.I. 2017. Cancionero Popular Vasco. Erein Argitaletxea.

[3] Aranburu Urtasun, M. 2020. Jauziak edo Iautziak, http://aunamendi.euskoikaskuntza.eus/eu/jauziak-edo-iautziak/ar-154101/. Auñamendi Eusko Enziklopedia, Bernardo Estornés Lasa Funtsa, Eusko Ikaskuntza.

[4] Aiko Taldea; Furundarena, A.; Bikandi, S.; García, A. 2010. Urraska: dantza-jauziak Sagasetaren bidetik. A new interpretation of The Basque Jauziak dances collected by Sagaseta. Center for Basques Studies; University of Nevada, Reno.

[5] Udaberri Dantza Taldea. 2019ko urriaren 17. 8. Gipuzkoako Brokel Dantza Zikloa; Uztaritze, https://www.youtube.com/watch?v=qoZZeakLnDA

[6] Sánchez Ekiza, K. 2020. Brokel-dantza, http://aunamendi.eusko-ikaskuntza. eus/eu/arin-arina-porrusalda/ar-3767/. Auñamendi Eusko Enziklopedia, Bernardo Estornés Lasa Funtsa, Eusko Ikaskuntza.

[7] De Etxebarria y Goiri, J.I. 1984. Bizkaiko dantzak, Danzas de Vizcaya. Colección Temas vizcainos, serie azul, Arte y Literatua, 115 y 116, Caja de Ahorros Vizcaina.

[8] Sánchez Ekiza, K. 2020. Fandangoa - Jota - Orripekoa -Trikitixa, http:// aunamendi.eusko-ikaskuntza.eus/artikuluak/artikulua.php?id=eu\&ar=64930. Auñamendi Eusko Enziklopedia, Bernardo Estornés Lasa Funtsa, Eusko Ikaskuntza. 
[9] Sánchez Ekiza, K. 2020. Arin-arina - Porrusalda, http://aunamendi.euskoikaskuntza.eus/eu/arin-arina-porrusalda/ar-3767/. Auñamendi Eusko Enziklopedia, Bernardo Estornés Lasa Funtsa, Eusko Ikaskuntza.

[10] Castellet, M., Llerena, I. 2000. Álgebra lineal y Geometría. Ed. Reverté.

[11] Dantzan.eus, 2018ko uztailaren 2. Berriz: San Pedro 1989 dantzari-dantza, https://dantzan.eus/bideoak/berriz-san-pedro-1989-dantzari-dantza

[12] García, M.A., Ramírez, D. 2012. Aljebra linealerako sarrera. OCW 2012, $\mathrm{UPV} / \mathrm{EHU}$.

[13] Dantzan.eus, 2015eko maiatzaren 25. Abadiño: San Trokaz 2015 Launangoa, https://dantzan.eus/bideoak/abadino-san-trokaz-2015-launangoa

[14] Artin, E. 1947. «Theory of Braids». Annals of Mathematics. 48 (1), 101-126.

[15] Gaztedi Dantzari Taldea, 2016ko otsailaren 29. Zinta-dantza, https://www. youtube $. c o m /$ watch? $\mathrm{v}=$ qoZZeakLnDA

[16] Larrinaga Zugadi, L. 2020. Zinta-Dantza, http://aunamendi.euskoikaskuntza.eus/eu/zinta-dantza/ar-147374/ . Auñamendi Eusko Enziklopedia, Bernardo Estornés Lasa Funtsa, Eusko Ikaskuntza.

[17] Hawksley, A. 2012. «Exploring Braids through Dance: The "Waves of Tory" Problem», Proceedings of Bridges 2012: Mathematics, Music, Art, Architecture, Culture. 612-618.

[18] Erreka-Ortu Euskal Dantza Taldea. 2018ko uztailaren 2. Iruleak Retuerto 2001, https://www.youtube.com/watch?v=YOULmuthIM8

[19] Tiam, M. 2019. «Maypole Braids: an analysis using the annular braid groups». Dickinson College Honor Thesis, Paper 323.

[20] Iribas, Basakaitz. 2015eko urriaren 22. Zinta Cortes Areso 2015, https:// www.youtube.com/watch?v=piOFFuFT9_Y 